University of Nebraska - Lincoln

DigitalCommons@University of Nebraska - Lincoln

Faculty Publications from the Harold W. Manter Laboratory of Parasitology

2005

\title{
Eimeria Species (Apicomplexa: Eimeriidae) from Arctic Ground Squirrels (Spermophilus parryii) and Red Squirrels (Tamiasciurus hudsonicus) in Alaska and in Siberia, Russia
}

\author{
Robert S. Seville \\ University of Wyoming, sseville@uwyo.edu \\ Clint E. Oliver \\ University of Wyoming \\ Andrew J. Lynch \\ University of New Mexico \\ Michelle C. Bryant \\ University of Wyoming \\ Donald W. Duszynski \\ University of New Mexico, eimeria@unm.edu
}

Follow this and additional works at: https://digitalcommons.unl.edu/parasitologyfacpubs

Part of the Parasitology Commons

Seville, Robert S.; Oliver, Clint E.; Lynch, Andrew J.; Bryant, Michelle C.; and Duszynski, Donald W., "Eimeria Species (Apicomplexa: Eimeriidae) from Arctic Ground Squirrels (Spermophilus parryii) and Red Squirrels (Tamiasciurus hudsonicus) in Alaska and in Siberia, Russia" (2005). Faculty Publications from the Harold W. Manter Laboratory of Parasitology. 146.

https://digitalcommons.unl.edu/parasitologyfacpubs/146

This Article is brought to you for free and open access by the Parasitology, Harold W. Manter Laboratory of at DigitalCommons@University of Nebraska - Lincoln. It has been accepted for inclusion in Faculty Publications from the Harold W. Manter Laboratory of Parasitology by an authorized administrator of DigitalCommons@University of Nebraska - Lincoln. 


\title{
EIMERIA SPECIES (APICOMPLEXA: EIMERIIDAE) FROM ARCTIC GROUND SQUIRRELS (SPERMOPHILUS PARRYII) AND RED SQUIRRELS (TAMIASCIURUS HUDSONICUS) IN ALASKA AND IN SIBERIA, RUSSIA
}

\author{
Robert S. Seville, Clint E. Oliver, Andrew J. Lynch, Michelle C. Bryant, and Donald W. Duszynski ${ }^{\star}$ \\ Department of Zoology and Physiology, University of Wyoming/Casper College Center, Casper, Wyoming 82601. e-mail: sseville@uwyo.edu
}

\begin{abstract}
Fecal samples from arctic ground squirrels (Spermophilus parryii) collected in Alaska $(\mathrm{n}=90)$ and Russia $(\mathrm{n}=46)$ and from red squirrels (Tamiasciurus hudsonicus) in Alaska $(\mathrm{n}=35)$ were examined for the presence of Eimeria spp. (Apicomplexa: Eimeriidae). Four species were recovered from arctic ground squirrels, including Eimeria callospermophili (prevalence $=$ 18\%), Eimeria cynomysis (23.5\%), Eimeria lateralis (19\%), and Eimeria morainensis (77\%). A single species, Eimeria tamiasciuri $(91 \%)$, was recovered from red squirrels. Eimerians recovered from arctic ground squirrels represent new host records, and the single species from red squirrels is a new geographic record. Alaskan arctic ground squirrel prevalence was higher for $E$. callospermophili $($ Alaska $=22 \%$ vs. Russia $=9 \%)$, E. cynomysis $(34 \%$ vs. $2 \%)$, and E. lateralis $(27 \%$ vs. $4 \%)$, but not E. morainensis $(78 \%$ vs. $76 \%)$.
\end{abstract}

Arctic ground squirrels (Spermophilus parryii (Richardsoni, 1825)) occur in northwest Canada, Alaska, United States, and northeast Russia. They are sciurid rodents that include 5 genera and $\sim 82$ species adapted to a predominately fossorial-terrestrial existence (Wilson and Reeder, 1993). Wilber et al. (1998) reviewed all published literature on the coccidia known from marmotine rodents and recognized and provided descriptions for 26 valid Eimeria species.

Red squirrels (Tamiasciurus hudsonicus Erxleben, 1777) range from Alaska through the northeastern United States south to South Carolina. Some sciurids in the Tribe Tamiasciurini (3 genera and $\sim 11$ species) are adapted primarily to an arboreal existence (Wilson and Reeder, 1993). To date, only 2 species of coccidia-Eimeria tamiasciuri Levine, Ivens \& Kruidenier, 1957, and Eimeria toddi Dorney, 1962-have been reported from red squirrels in the continental United States (Levine and Ivens, 1990).

In collaboration with the Beringian Coevolution project, which is systematically inventorying the mammals and associated parasites and pathogens of the Beringian region, we received feces from arctic ground squirrels collected from 2 unnamed locations and 5 national preserves in Alaska and 12 locations in northeastern Russia and red squirrels collected from 4 national preserves in Alaska. Here, we report results of our survey of eimerian species in arctic ground squirrels and red squirrels from these 2 regions and taxonomic details for the species recovered.

\section{MATERIALS AND METHODS}

Arctic ground squirrels were collected by shooting from 2 locations and 5 national preserves in Alaska (Bering Land Bridge National Preserve, Cape Krusenstern National Monument, Noatak National Preserve, Wrangle-St. Elias National Park [W-SENP], and Yukon-Charley Rivers National Preserve [Y-CRNP]), United States, and 12 locations in Magadanskaya oblast and Chukotka, Russia, during the summers of 2000, 2001, and 2002. Red squirrels were collected in Alaska from Kobuk Valley National Park, W-SENP, and Y-CRNP in 2001. Details regarding mammal collection are provided in Edingsaas et al. (2004). Fresh fecal samples were obtained from the colon of each host in the field and stored in vials containing $2 \%(\mathrm{w} / \mathrm{v})$ aqueous potassium dichromate at ambient temperature to allow oocyst sporulation until ex-

Received 10 September 2004; revised 10 November 2004; accepted 6 December 2004

* Department of Biology, The University of New Mexico, Albuquerque, New Mexico 87131. amination at the University of Wyoming/Casper College Center and the University of New Mexico. Oocysts were isolated by flotation in saturated sucrose solution (specific gravity $=1.2$ ) and identified with oil immersion lenses on a compound microscope with bright field and Nomarski differential interference contrast microscopy. Standardized abbreviations for oocyst and sporocyst characters, with a single exception ( sporozoites $=$ SZ), are those recommended by Wilber et al. (1998), including oocyst characters length (L) and width (W) - their ranges and ratio $(\mathrm{L} / \mathrm{W})$-micropyle $(\mathrm{M})$, residuum $(\mathrm{OR})$, and polar granules $(\mathrm{PG})$ and sporocyst characters length (L), width (W) - their ranges and ratio (L/W) — stieda body (SB), substieda body (SSB), parastieda body (PSB), residuum (SR), refractile bodies (RB), and nucleus (N). Measurements of standard morphologic parameters were made with an ocular micrometer and are reported as an average $(\mu \mathrm{m})$ followed by the range in parentheses. Photomicrographs were produced, and photovouchers of sporulated oocysts were accessioned into the U.S. National Parasite Collection (USNPC), Beltsville, Maryland.

\section{RESULTS}

Fecal samples from 136 arctic ground squirrels and 35 red squirrels were examined, and 118 of the former and 32 of the latter were positive for the presence of Eimeria (87 and 91\%, respectively). Four species were identified from arctic ground squirrels, including Eimeria callospermophili (prevalence = $18 \%$ ), Eimeria cynomysis (23.5\%), Eimeria lateralis (19\%), and Eimeria morainensis $(77 \%)$. Only a single species, E. tamiasciuri $(91 \%)$, was identified from red squirrels. Table I presents summary data on prevalences for each species in each geographic region. Arctic ground squirrel species richness (number of eimerian species per animal/number hosts examined) was 1.4 , with 67 animals (49.2\%) having single-species infections and $35(25.7 \%)$ with 2 species, $14(10.3 \%)$ with 3 species, and $2(1.5 \%)$ with 4 species infecting simultaneously.

\section{DESCRIPTION}

\section{Eimeria callospermophili Henry, 1932}

Oocyst shape spheroid to subspheroid; wall $\sim 1-2$ thick, with 2 layers: outer layer smooth and approximately two thirds of total thickness; $\mathrm{L} \times \mathrm{W}(\mathrm{n}=13) 23.5 \times 20.9(19-25.5 \times 16.5-26) ; \mathrm{L} / \mathrm{W} 1.1(1-1.2)$ $\mathrm{M}$ absent; OR present; OR characteristics compact, homogeneous mass, granular or smooth, 3-6 $\times 3-6$; PG usually 1 , but up to 4 present. Sporocysts $(n=10)$ lemon-shaped; $\mathrm{L} \times \mathrm{W} 10.5 \times 8.2(9-14 \times 7-9)$; L/W 1.3 (1-1.6); SB present and nipplelike; SSB, PSB both absent; SR present as few dispersed granules. 
TABLE I. Country of origin, locations, geographic coordinates, sample sizes, and eimerian species present (number of animals infected) for samples collected from arctic ground squirrels (Spermophilus parryii).

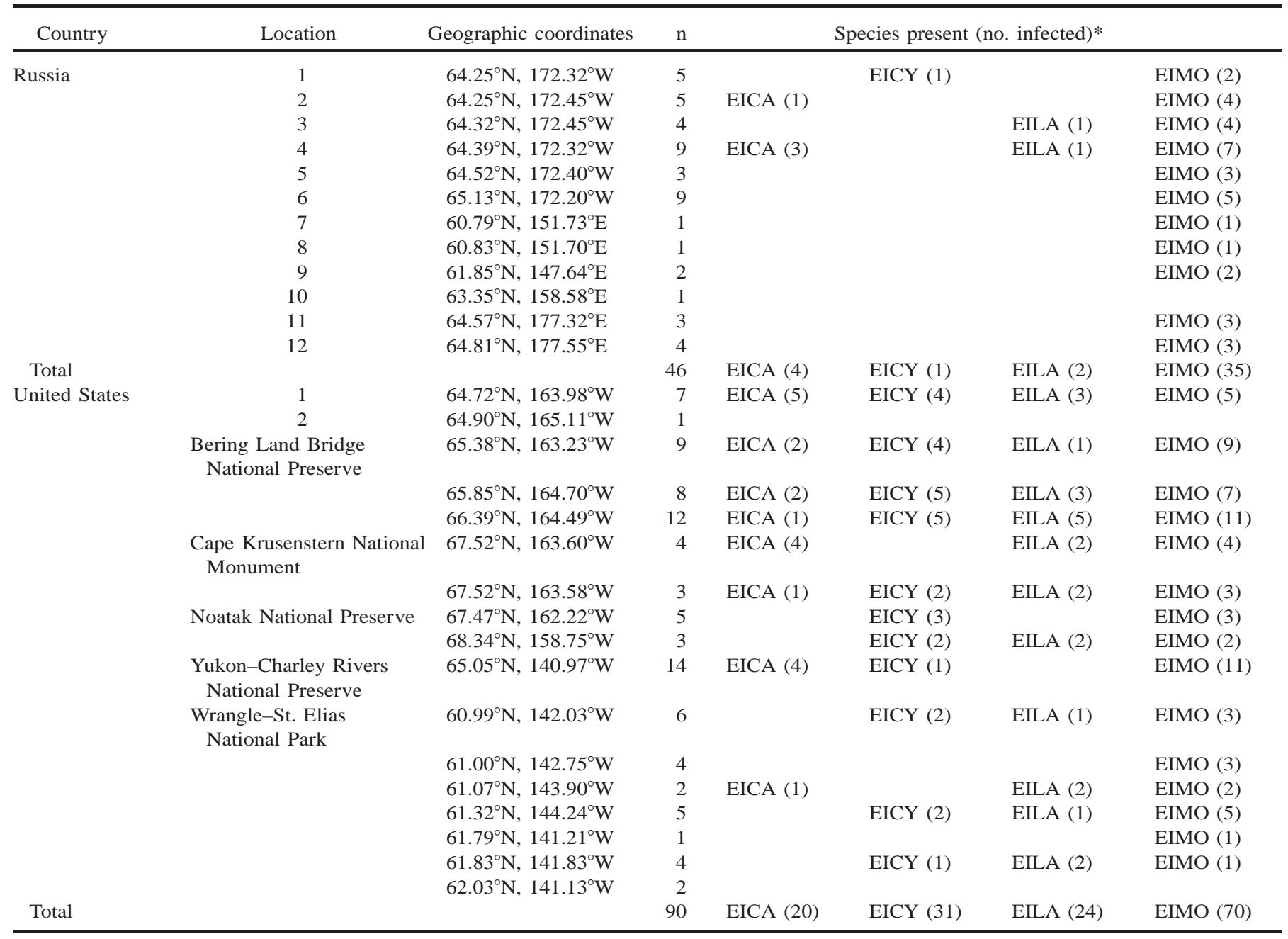

* Abbreviation: EICA, Eimeria callospermophili; EICY, Eimeria cynomysis; EILA, Eimeria lateralis; EIMO, Eimeria morainensis.

\section{Taxonomic summary}

Synonyms: Seven (see Wilber et al., 1998).

Type host: Spermophilus lateralis (Say, 1823), golden-mantled ground squirrel.

Other hosts: Twenty-five species in the genera Cynomys (3 species), Marmota (5), and Spermophilus (17) (see Wilber et al., 1998); S. parryii (this study).

Type locality: North America: Placer County, California, United States.

Geographic distribution: Asia: Kazakhstan, Buriatia. North America: Alberta, Canada; Mexico; Colorado, Idaho, Illinois, Iowa, Montana, New York, New Mexico, Pennsylvania, Texas, Utah, and Wyoming, United States. In 2000-2003, collected from S. parryii in Alaska and in Magadanskaya oblast and Chukotka, Russia (this study).

Prevalence: One of three (33\%) in type host; 76 of 123 (63\%) Cynomys gunnisoni from Utah (Thomas and Stanton, 1994); 43 of 61 (71\%) Cynomys leucurus and 25 of 39 (64\%) Cynomys ludovicianus from Wyoming (Seville, 1997); 2 of 2 (100\%) Spermophilus beecheyi from California (Henry, 1932); 211 of 1,007 (21\%) and 36 of 69 (52\%) Spermophilus elegans from Wyoming (Shults et al., 1990); 36 of 100 (36\%) Spermophilus richardsonii from Alberta, Canada (Seville and Stanton, 1993); 5-80\% Spermophilus townsendii in Idaho (Wilber et al., 1994); 6 of 81 (7\%) Spermophilus undulatus from Kazakhstan (Matschoulsky, 1949); 4 of 7 (57\%) Spermophilus variegatus from Utah (Thomas and Stanton, 1994); and 20 of $90(22 \%)$ and 4 of $46(9 \%) S$. parryii from Alaska and Magadanskaya oblast and Chukotka, Russia, respectively (this study).

Sporulation: From 2.5 to 7 days (Crouch and Becker, 1931; Henry, 1932; Todd and Hammond, 1968a).

Prepatent period: Five to six days (Todd and Hammond, 1968a).

Patent period: Nine days (Todd and Hammond, 1968a).

Site of infection: Endogenous stages most numerous in the jejunum and upper ileum. The epithelium of the entire villus infected, but the endogenous stages were usually concentrated at the tips and along the distal one third. There was no observed pathogenicity (Todd and Hammond, 1968a).

Materials deposited: Photovouchers of sporulated oocysts from $S$. parryii deposited in USNPC 95305 (Russia) and 95306 (Alaska).

\section{Remarks}

The description of E. callospermophili from arctic ground squirrels from Alaska and Russia is similar to the composite description developed by reviewing all published descriptions of this species from all marmotine hosts by Wilber et al. (1998). In addition, the arctic ground squirrel specimens had 2-layered oocyst walls, with the outer layer two thirds of the total thickness; were slightly larger $(\mathrm{L} \times \mathrm{W}=23.5 \times 20.9$ vs. $19.2 \times 16.0)$; but had similar subspheroid sporocysts $(\mathrm{L} \times \mathrm{W}=$ $10.5 \times 8.2$ vs. $10.2 \times 8.5$ ), with SR consisting of few dispersed granules.

When oocysts from Alaska $(n=8)$ and Russia $(n=5)$ were com- 
pared, few differences were noted. Oocyst $\mathrm{L} \times \mathrm{W}$ was similar (Alaska $=23.7 \times 20.8$ vs. Russia $=23.2 \times 21.0)$, but Russian sporocysts were larger $(\mathrm{L} \times \mathrm{W}=11.3 \times 9.0$ vs. $10.1 \times 7.8)$.

\section{Eimeria cynomysis Andrews, 1928}

Oocyst shape ovoid; wall $\sim 1.5$ thick, with 2 layers: outer layer yellow/brown, rough; $\mathrm{L} \times \mathrm{W}(\mathrm{n}=28) 35.9 \times 28.1(34-39.5 \times 25.6$ 32.5); L/W 1.3 (1.4-1.2); $\mathrm{M}$ present, 5.7-10 wide; MC absent; OR absent; 0-1 PG present. Sporocysts $(\mathrm{n}=18)$ ovoid; $\mathrm{L} \times \mathrm{W} 18.2 \times$ $10.1(14-21 \times 8-12) ;$ L/W 1.9 (1.6-2.1); SB present; SSB and PSB both absent; SR present as small granular mass or occasionally as large, membrane-bound granular mass located centrally between the sporozoites or occasionally below the SB.

\section{Taxonomic summary}

Synonyms: Two (see Wilber et al., 1998).

Type host: Cynomys ludovicianus (Ord, 1815), the black-tailed prairie $\operatorname{dog}$

Other hosts: Thirteen in Cynomys (2) and Spermophilus (11) (see Wilber et al., 1998); S. parryii (this study).

Type locality: North America: Ohio, United States (animals from a supply house, origin unknown, but analysis done in Ohio).

Geographic distribution: Europe: Czech Republic. North America: Alberta, Canada; California, Colorado, Idaho, Iowa, Ohio, Utah, and Wyoming, United States. In 2000-2003, collected from S. parryii in Alaska and in Magadanskaya oblast and Chukotka, Russia (this study).

Prevalence: Two of two (100\%) in type host; 12 of $123(10 \%) C$. gunnisoni from Utah (Thomas and Stanton, 1994); 3 of 18 (17\%; Shults et al., 1990) and 1 of 61 (2\%; Seville, 1997) C. leucurus from Wyoming; 9 of 26 (35\%) Spermophilus columbianus from Alberta, Canada (Hilton and Mahrt, 1971); 121 of 1,007 (12\%; Shults et al., 1990) and $11 \%$ (number infected and sample size not reported; Seville et al., 1996) S. elegans from Wyoming; 2 of 8 (25\%) Spermophilus franklinii from Alberta, Canada (Hilton and Mahrt, 1971); 2 of 3 (66\%) S. lateralis from California (Henry, 1932); 6 of 100 (6\%; Seville and Stanton, 1993) and 13 of 121 (11\%; Hilton and Mahrt, 1971) S. richardsonii from Alberta, Canada; 35 of 788 (4\%) S. townsendii from Idaho (Wilber et al., 1994); 6 of 18 (19\%) from Iowa (Kietzmann and Kietzmann, 1987) and 2 of 56 (4\%) Spermophilus tridecemlineatus from Wyoming (Seville et al., 1992); 2 of 7 (29\%) S. variegatus from Utah (Thomas and Stanton, 1994); and 31 of 90 (34\%) from Alaska and 1 of 46 (2\%) S. parryii from Magadanskaya oblast and Chukotka, Russia (this study).

Sporulation: Eight to eleven days (Henry, 1932; Hall and Knipling, 1935; Todd et al., 1968).

Prepatent period: Ten to eleven days (Todd et al., 1968).

Patent period: Five to twenty-one days (Todd et al., 1968).

Site of infection: Todd et al. (1968) observed endogenous stages in the tips of the villi in the ileum and jejunum, but not in the duodenum. Little cell damage was observed, but infections did cause pathogenicity. Oocysts used for description recovered from feces.

Materials deposited: Phototype of sporulated oocyst in USNPC 87250. Photovouchers of sporulated oocysts from $S$. parryii deposited in USNPC 95307 (Alaska) and 95308 (Russia).

\section{Remarks}

The description of oocysts of E. cynomysis from arctic ground squirrels is consistent with the composite description developed by Wilber et al. (1998). Oocysts from arctic ground squirrels were longer and narrower $(\mathrm{L} \times \mathrm{W}=35.9 \times 28.1$ vs. $35.4 \times 30.0)$, making them more ellipsoidal (L/W 1.3 vs. 1.2); the micropyle width was more variable (6-10 vs. 5-6); the sporocysts were larger $(\mathrm{L} \times \mathrm{W}=18.2 \times 10.1 \mathrm{vs}$. no average reported, range $14-20 \times 8-11.5$ vs. $13-17 \times 8-12$ ); and the SR was either a small or large membrane-bound granular mass rather than coarsely granular in large amounts.

When oocysts from Alaska $(n=8)$ and Russia $(n=20)$ were compared, only minor differences were observed. Oocyst $\mathrm{L} \times \mathrm{W}$ was similar $($ Alaska $=36.4 \times 28.0$ vs. Russia $=35.7 \times 28.2)$; Alaska sporocysts were smaller $(\mathrm{L} \times \mathrm{W}=17.3 \times 9.3$ vs. $18.9 \times 10.6)$; and oocysts from Alaska had a wider micropyle than those from Russia ( $\mathrm{MW}=7.2$ vs. 8.8).

\section{Eimeria lateralis Levine, Ivens, and Kruidenier, 1957}

Oocyst shape ellipsoid to ovoid; wall $\sim 2$ thick, with 2 layers: outer layer rough, yellow/brown, and approximately two thirds of total thickness; $\mathrm{L} \times \mathrm{W}(\mathrm{n}=42) 31.7 \times 24.7(27-37.5 \times 20-28)$; L/W $1.3(1.1-$ 1.5); M absent; OR absent; PG 0-4 present. Sporocysts $(\mathrm{n}=43)$ ovoidal, $\mathrm{L} \times \mathrm{W} 15.8 \times 10.0(12-18 \times 9-11) ; \mathrm{L} / \mathrm{W} 1.6(1.4-1.8) ; \mathrm{SB}$ present, nipplelike; SSB and PSB both absent; SR present as numerous, large granules dispersed throughout sporocyst or along edge of sporocyst.

\section{Taxonomic summary}

Synonyms: Five (see Wilber et al., 1998).

Type host: Spermophilus lateralis.

Other hosts: Eighteen in the genera Cynomys (3), Marmota (3), Spermophilus (10), and Tamias (2) (see Wilber et al., 1998); S. parryii (this study).

Type locality: North America: Point Imperial, Arizona, on the North Rim of the Grand Canyon, Grand Canyon National Park, United States.

Geographic distribution: Asia: Kazakhstan. North America: Alberta, Canada; Baja California, Mexico; Arizona, California, Colorado, Idaho, Illinois, Massachusetts, Montana, New York, Pennsylvania, Utah, Wisconsin, and Wyoming, United States. In 2000-2003, collected from $S$. parryii in Alaska and in Magadanskaya oblast and Chukotka, Russia (this study).

Prevalence: One of one (100\%) in type host; 4 of $123(3 \%)$ C. gunnisoni from Utah (Thomas and Stanton, 1994); 4 of 17 (24\%) C. leucurus from Wyoming (Seville and Williams, 1989); 4 of 86 (5\%) C. ludovicianus from Colorado (Vetterling, 1964); 4 of 25 (16\%) Marmota monax (Dorney, 1965) from Pennsylvania; 21 of $38(55 \%)$ M. monax from Illinois (McQuistion and Wright, 1984); 39 of 232 (17\%) M. monax from New York (Fleming et al., 1979); 2 of 36 (6\%) Spermophilus beldingi from California (Veluvolu and Levine, 1984); 2 of $36 \mathrm{~S}$. columbianus from Alberta, Canada (Hilton and Mahrt, 1971); 168 of 1,007 (17\%) S. elegans from Wyoming (Shults et al., 1990); 3 of 69 (4\%) S. elegans from Wyoming (Shults et al., 1990); 18 of 121 (15\%) S. richardsonii from Alberta, Canada (Hilton and Mahrt, 1971); 6 of 100 (6\%) S. richardsonii from Alberta, Canada (Seville and Stanton, 1993); $1-5 \%$ S. townsendii from Idaho (Wilber et al., 1994); 9 of 56 (16\%) S. tridecemlineatus from Wyoming (Seville et al., 1992); 3 of 96 (3\%) Tamias obscurus from Baja California, Mexico (Hill and Duszynski, 1986); 12 of 84 (14\%) Tamias striatus from Wisconsin (Dorney, 1962); 6 of 75 (8\%) T. striatus from Massachusetts (Duncan, 1968); 21 of 189 (11\%) T. striatus from Wisconsin (Dorney 1963, 1966); 3 of 41 (9\%) T. striatus from Pennsylvania (Seville and Patrick, 2001); and 24 of 90 (27\%) from Alaska and 2 of $46(4 \%)$ S. parryii from Magadanskaya oblast and Chukotka, Russia (this study).

Sporulation: Two to four weeks at room temperature (Dorney, 1962); $50 \%$ of oocysts sporulated after 49 days in the laboratory (Dorney, 1965); 7-10 days in the laboratory (Vetterling, 1964); 10-14 days at room temperature (Duncan, 1968).

Prepatent period: Five days in Spermophilus armatus (Todd and Hammond, 1968b).

Patent period: Six and a half days in S. armatus (Todd and Hammond, 1968b).

Site of infection: Dorney (1962) observed endogenous stages primarily in the middle of the small intestine of M. monax (Dorney, 1962). Todd and Hammond (1968b) observed endogenous stages in the epithelial cells of the jejunum and ileum of experimentally infected $S$. armatus.

Materials deposited: Phototype of sporulated oocyst in USNPC 87251. Symbiotype in University of Illinois Natural History Museum 10300. Photovouchers of sporulated oocysts from S. parryii deposited in USNPC 95309 (Alaska) and 95310 (Russia).

\section{Remarks}

The description of E. lateralis from arctic ground squirrels is similar to the composite description by Wilber et al. (1998). Overall, the oocysts were smaller $(\mathrm{L} \times \mathrm{W}=31.7 \times 24.7$ vs. $35.1 \times 26.8)$ and more ellipsoid $(\mathrm{L} / \mathrm{W}=1.6$ vs. 1.3$)$. The sporocysts were similar in size (L $\times \mathrm{W}=16 \times 10)$ and had a prominent $\mathrm{SB}$, and the SR was present as numerous large, dispersed granules.

When oocysts from Alaska $(n=4)$ and Russia $(n=39)$ were com- 
pared, oocysts were similar in all respects, including $\mathrm{L} \times \mathrm{W}$ (Alaska $=32.6 \times 24.8$ vs. Russia $=31.7 \times 24.7) ; \mathrm{L} / \mathrm{W}(1.3$ vs. 1.2$)$, and sporocyst size $(\mathrm{L} \times \mathrm{W}=15.5 \times 10.1$ vs. $15.8 \times 10.0)$.

\section{Eimeria morainensis Torbett, Marquardt, and Carey, 1982}

Oocyst shape subspheroid; wall 1-1.5, with 2 layers of equal thickness; $\mathrm{L} \times \mathrm{W}(\mathrm{n}=47) 23.3 \times 19.5(19.5-28 \times 14-22.5)$; L/W $1.2(1-$ 1.4); M absent; OR absent; PB 0-3 present, often bilobed. Sporocysts ellipsoidal; $\mathrm{L} \times \mathrm{W}(\mathrm{n}=37) 11.7 \times 7.4(7.9-14.0 \times 5.5-9.0) ; \mathrm{L} / \mathrm{W} 1.6$ (1.3-2); SB present and usually prominent, dark and buttonlike; SR present as compact, occasionally membrane-bound granular mass, dispersed granules, or both.

\section{Taxonomic summary}

Type host: Spermophilus lateralis.

Other hosts: Nine in the genera Cynomys (3), Marmota (1), Spermophilus (5) (see Wilber et al., 1998); S. parryii (this study).

Type locality: North America: Moraine Park in Rocky Mountain National Park, Colorado (T5N, R73W, S29), United States.

Geographic distribution: North America: Alberta, Canada; Colorado, Idaho, Utah, and Wyoming, United States. In 2000-2003, collected from $S$. parryii in Alaska and in Magadanskaya oblast and Chukotka, Russia (this study).

Prevalence: One of thirty-five (3\%) in type host; 4 of 18 (22\%) C. leucurus from Wyoming (Shults et al., 1990); 435 of 1,007 (43\%) S. elegans from Wyoming (Shults et al., 1990); 36 of 69 (52\%) S. elegans from Wyoming (Shults et al., 1990); 1 of 35 (3\%) S. lateralis from Colorado (Torbett et al., 1982); 5-18\% S. townsendii from Idaho (Wilber et al., 1994); 6 of 7 (86\%) S. variegatus from Utah (Thomas and Stanton, 1994); and 70 of 90 (78\%) from Alaska and 35 of $46(76 \%)$ S. parryii from Magadanskaya oblast and Chukotka, Russia (this study). Sporulation: Six to seven days (Torbett et al., 1982)

Prepatent period: Eight to nine days (Torbett et al., 1982).

Patent period: Nine days (Torbett et al., 1982).

Site of infection: Unknown. Oocysts recovered from feces.

Materials deposited: Photoype of sporulated oocyst in USNPC 82933. Photovouchers of sporulated oocysts from S. parryii deposited in USNPC 95311-95313 (Russia).

\section{Remarks}

The description of E. morainensis from arctic ground squirrels is similar to the composite description by Wilber et al. (1998). Oocysts were larger $(\mathrm{L} \times \mathrm{W}=23.3 \times 19.5$ vs. $20.3 \times 19.8)$, had shorter but wider sporocysts $(\mathrm{L} \times \mathrm{W}=11.7 \times 7.4$ vs. $12.1 \times 6.9)$, and possessed a buttonlike SB and a membrane-bound granular SR, or a row of globules along side the sporocyst wall, or both

When oocysts from Alaska $(n=30)$ and Russia $(n=17)$ were compared, oocysts were similar in all respects. Russian oocysts were larger $(\mathrm{L} \times \mathrm{W}=23.4 \times 20.0$ vs. $23.2 \times 19.2)$, but sporocyst size was similar $(\mathrm{L} \times \mathrm{W}=11.9 \times 7.4$ vs. $11.8 \times 7.4)$

\section{Eimeria tamiasciuri Levine, Ivens, and Kruidenier, 1957}

Oocyst shape elongate ellipsoid; L $\times \mathrm{W} 29 \times 16$; M absent; OR absent; PB present. Sporocysts ellipsoidal; L $\times$ W $13 \times 7$; SB coneshaped.

\section{Taxonomic summary}

Type host: Microtus montanus (Peale, 1848), the montane vole. Other hosts: Sciurus aberti Woodhouse, 1853; Sciurus griseus Ord, 1818; Tamias dorsalis Baird, 1855; Tamias merriami J.A. Allen, 1889; T. obscurus J.A. Allen, 1889; Tamiasciurus mearnsi (Townsend, 1897); T. hudsonicus.

Type locality: North America: north rim of the Grand Canyon, near the entrance to Grand Canyon National Park, Arizona, United States.

Geographic distribution: North America: Baja California, Mexico; California, New Mexico, and Wisconsin, United States. In 2000-2003, collected from T. hudsonicus in Alaska (this study).

Prevalence: One of five (20\%) in type host; 3 of 9 (33\%) S. abert from Arizona (Hill and Duszynski, 1986); 4 of 11 (36\%) S. aberti from New Mexico (Patrick and Wilson, 1995); 1 of 1 (100\%) S. griseus from
California (Hill and Duszynski, 1986); 1 of 12 (8\%) T. dorsalis from Arizona (Hill and Duszynski, 1986); 1 of 50 (2\%) T. merriami from California (Hill and Duszynski, 1986); 1 of 96 (1\%) T. obscurus from Baja California Norte, Mexico (Hill and Duszynski, 1986); 3 of 5 (60\%) T. mearnsi from Baja California Norte, Mexico (Hill and Duszynski, 1986); 2 of 2 (100\%) T. hudsonicus from New Hampshire (Bullock, 1959); 49 of 50 (98\%) T. hudsonicus from Wisconsin (Dorney, 1962); 149 of 152 (98\%) T. hudsonicus from Wisconsin (Dorney, 1966); 12 of 13 (92\%) T. hudsonicus from Ontario, Canada (Soon and Dorney, 1969); 166 of 171 (97\%) T. hudsonicus from Alberta, Canada (Mahrt and Chai, 1970); 88 of 89 (99\%) T. hudsonicus from Alberta (Mahrt and Chai, 1972); 3 of 12 (25\%) T. hudsonicus from New Mexico (Patrick and Wilson, 1995); 1 of $1(100 \%)$ T. h. mogollonensis from Arizona (Hill and Duszynski, 1986); and 32 of 35 (91\%) T. hudsonicus from Alaska (this study: 28/31 [90\%] Yukon Charley; $2 / 2$ [100\%] Wrangle St. Elias; 2/2 [100\%] Kobuk).

Sporulation: Three days (Soon and Dorney, 1969).

Prepatent period: Unknown.

Patent period: Unknown.

Site of infection: Unknown. Oocysts recovered from feces.

Materials deposited: Phototype of sporulated oocyst in USNPC 87256. No photovoucher from this host produced.

\section{Remarks}

The description of E. tamiasciuri from red squirrels from Alaska is similar to the original description by Levine et al. (1957) from the same host species in Arizona. Oocysts and sporocysts were smaller (oocyst $\mathrm{L} \times \mathrm{W}=29 \times 16$ vs. $33 \times 19$; sporocyst $\mathrm{L} \times \mathrm{W}=13 \times 7$ vs. $16 \times$ 8 ), but there were no differences in overall morphology, including the elongate ellipsoid oocyst shape and cone-shaped SB. The recovery of E. tamiasciuri from $T$. hudsonicus establishes a new geographic record for the parasite.

\section{DISCUSSION}

Previously, Wilber et al. (1998) suggested that because members of the rodent tribe Marmotini arose fairly recently and are likely to harbor closely related parasites and that few crosstransmission or molecular studies have been conducted, the morphologic species concept was the only practical approach to naming and identifying Eimeria spp. in this rodent group. Comparison of the morphologies of the different species we observed in samples from arctic ground squirrels from both continents and with species reported from other marmotine hosts from other regions strongly supports conspecificity both across the different marmotine host species and between the eimerians recovered from arctic ground squirrels in Russia and in Alaska. However, because Alaska marmotine populations and their parasites have likely been isolated from Russia since the last Beringian land bridge, which was broken approximately $15,500 \mathrm{yr}$ ago (Pielou, 1991), we suggest that molecular and cross-transmission studies be conducted to verify conspecificity.

Prevalences for all species in arctic ground squirrels except E. morainensis were significantly higher for the Alaskan than the Russian populations (Table I). Although we cannot offer a definitive explanation, one plausible reason could be that Alaskan samples were collected from National Parklands, so estimated prevalences represent undisturbed conditions, whereas Russian populations might have been subject to human disturbance via habitat disruption or squirrel population control, although we are unable to confirm this possibility.

There have been few surveys of arctic sciurids for coccidia, and this is the first to examine a large number of samples from a single host species. Arctic marmotine hosts not adequately sampled include Marmota broweri, Marmota caligata, Marmota camtschatica, and Tamias sibiricus. Being the first survey 
of arctic ground squirrels and red squirrels in Beringia for coccidia, this report constitutes new host and geographic ranges for E. callospermophili, E. cynomysis, E. lateralis, and E. morainensis and a new geographic record for E. tamiasciuri in red squirrels. Eimeria cynomysis and E. morainensis are now documented to occur from the central United States to arctic Alaska and eastern Russia, E. callospermophili and E. lateralis from Mexico to arctic Alaska and eastern Russia, and E. tamiasciuri from Alaska to Mexico and the eastern United States.

\section{ACKNOWLEDGMENTS}

Fecal samples from arctic ground squirrels and red squirrels were collected as part of the Beringian Coevolution Project (BCP) funded by the NSF (DBI-0196095 to J. A. Cook). We thank all of the biologists of the various $\mathrm{BCP}$ field teams for their diligent efforts in providing specimens from remote field camps of Beringia. Angela Hick processed some of the samples. Additional support was provided by the University of Wyoming/Casper College Center, University of Wyoming Department of Zoology and Physiology, and the UW-NIH BRIN (Biomedical Research Infrastructure Network) and UW-NSF EPSCoR programs.

\section{LITERATURE CITED}

Bullock, W. L. 1959. The occurrence of Eimeria tamiasciuri in New Hampshire. Journal of Parasitology 45: 39-40.

Crouch, H. B., AND E. R. BeCKER. 1931. Three species of coccidia from the woodchuck, Marmota monax. Iowa State College Journal of Science 2: 127-131.

Dorney, R. S. 1962. A survey of the coccidia of some Wisconsin Sciuridae with descriptions of three new species. Journal of Protozoology 9: $258-261$.

. 1963. Coccidiosis-Incidence, epizootiology, in two Wisconsin Sciuridae. North American Wildlife Natural Resources Conference 28: $207-215$.

- 1965. Eimeria tuscarorensis n. sp. (Protozoa: Eimeriidae) and redescriptions of other coccidia of the woodchuck, Marmota monax. Journal of Protozoology 12: 423-426.

. 1966. Quantitative data on four species of Eimeria in eastern chipmunks and red squirrels. Journal of Protozoology 13: 549-550.

Duncan, S. 1968. Eimeria ovata n. sp. and other coccidia of the eastern chipmunk Tamias striatus in Massachusetts. Journal of Protozoology 15: 319-320.

EddingsaAs, A. A., B. K. Jacobsen, E. P. Lessa, and J. P. Cook. 2004. Evolutionary history of the arctic ground squirrel (Spermophilus parryii) in nearctic Beringia. Journal of Mammology 85: 601-610.

Fleming, W. J., J. R. Georgi, AND J. W. Caslick. 1979. Parasites of the woodchuck (Marmota monax) in central New York State. Proceedings of the Helminthological Society of Washington 46: 115-127.

Hall, P. R., AND E. F. KNIPLING. 1935. Eimeria franklinii and Eimeria eubeckeri, two new species of coccidia from the Franklin ground squirrel, Citellus franklinii Sabine. Journal of Parasitology 21: 128129.

HenRY, D. P. 1932. Observations on the coccidia of small mammals in California, with descriptions of seven new species. University of California Publications in Zoology 37: 279-290.

HiLl, T. P., AND D. W. Duszynski. 1986. Coccidia (Apicomplexa: Eimeriidae) from sciurid rodents (Eutamias, Sciurus, Tamiasciurus spp.) from the Western U.S.A. and northern Mexico and descriptions of two new species. Journal of Protozoology 33: 282-288.

Hilton, D. F. J., AND J. L. MAHRT. 1971. Eimeria spermophili n. sp. and other Eimeria spp. (Sporozoa, Eimeriidae) from three species of Alberta Spermophilus (Rodentia, Sciuridae). Canadian Journal of Zoology 49: 699-701.

Kietzmann, J. G. E., And E. A. KietZmann. 1987. Parasites associated with thirteen-lined ground squirrels (Spermophilus tridecemlineatus Mitchill) from Ames, Iowa. Proceedings of Iowa Academy of Sciences 94: 22-23.

LeVINE, N. D., AND V. Ivens. 1990. The coccidian parasites of rodents. CRC Press, Boca Raton, Florida, 228 p. from Arizona rodents. Journal of Protozoology 4: 80-88.

MahrT, J. L., AND S. J. Chai. 1970. Prevalence of coccidia in red squirrels (Tamiasciurus hudsonicus) in Alberta. Canadian Journal of Zoology 48: 606.

— AND — 1972. Parasites of red squirrels in Alberta, Canada. Journal of Parasitology 58: 639-640.

MatsChOULSKY, S. N. 1949. About coccidia in rodents of southern areas of Buryat-Mongol, U.S.S.R. Trudy Buryet-Mongol'skoi Zooveterinarnogo Instituta, Ulan-Ude 5: 40-56.

McQuistion, T. E., AND J. M. Wright. 1984. The prevalence and seasonal distribution of coccidial parasites of woodchucks (Marmota marmota). Journal of Parasitology 70: 994-996.

PAtrick, M. J., AND W. D. Wilson. 1995. Parasites of the Abert's squirrel (Sciurus aberti) and red squirrel (Tamiasciurus hudsonicus) of New Mexico. Journal of Parasitology 81: 321-324.

Pielou, E. C. 1991. After the Ice Age. University of Chicago Press, Chicago, Illinois, $366 \mathrm{p}$.

Seville, R. S. 1997. Eimeria spp. (Apicomplexa: Eimeriidae) from black- and white-tailed prairie dogs (Cynomys ludovicianus and Cynomys leucurus) in central and southeast Wyoming. Journal of Parasitology 83: 166-168.

- AND M. J. PATRICK. 2001. Eimeria spp. (Apicomplexa: Eimeriidae) from the eastern chipmunk (Tamias striatus) in Pennsylvania with a description of one new species. Journal of Parasitology 87: $165-168$

-, AND N. L. Stanton. 1993. Eimerian guilds (Apicomplexa: Eimeriidae) in Richardson's (Spermophilus richardsonii) and Wyoming (Spermophilus elegans) ground squirrels. Journal of Parasitology 79: 973-975.

, $\longrightarrow$, AND K. GEROw. 1996. Stable parasite guilds: Coccidia in spermophiline rodents. Oikos 75: 365-372.

, D. M. Thomas, R. Pickering, and N. L. Stanton. 1992. Species of Eimeria from the thirteen-lined ground squirrel, Spermophilus tridecemlineatus from Wyoming. Great Basin Naturalist 52: 309-312.

— prairie dog Cynomys leucurus at Meeteetse, Park County, Wyoming USA. Proceedings of the Helminthological Society of Washington 56: $204-206$.

Shults, L. M., R. S. Seville, N. L. Stanton, and G. Menkens JR. 1990. Eimeria sp. (Apicomplexa: Eimeriidae) from Wyoming ground squirrels, Spermophilus elegans, and white-tailed prairie dogs, Cynomys leucurus, in Wyoming. Great Basin Naturalist 50: 327-331.

SoOn, B. L., AND R. S. DoRney. 1969. Occurrence of Eimeria tamiasciuri in Ontario red squirrels (Tamiasciurus hudsonicus). Canadian Journal of Zoology 47: 731-732.

Thomas, D. M., AND N. L. Stanton. 1994. Eimerian species (Apicomplexa: Eimeriina) in Gunnison's prairie dogs (Cynomys gunnisoni zuniensis) and rock squirrels (Spermophilus variegatus grammurus) from southeastern Utah. Journal of the Helminthological Society of Washington 61: 17-21.

Todd, J. K. S., AND D. M. Hammond. 1968a. Life cycle and host specificity of Eimeria callospermophili Henry, 1932 from the Uinta ground squirrel Spermophilus armatus. Journal of Protozoology 15: $1-8$.

- AND - 1968b. Life cycle and host specificity of Eimeria larimerensis Vetterling, 1964, from the Uinta ground squirrel Spermophilus armatus. Journal of Protozoology 15: 268-275.

- , AND L. C. ANDERSON. 1968. Observations on the life cycle of Eimeria bilamellata Henry, 1932 in the Uinta ground squirrel Spermophilus armatus. Journal of Protozoology 15: 732 740.

Torbett, B. E., W. C. Marquardt, and A. C. Carey. 1982. A new species of Eimeria from the golden mantled ground squirrel, Spermophilus lateralis, in northern Colorado. Journal of Protozoology 29: $157-159$.

Veluvolu, P., And N. D. Levine 1984. Eimeria beldingii n. sp. and other coccidia (Apicomplexa) of the ground squirrel Spermophilus beldingi. Journal of Protozoology 31: 357-358.

Vetterling, J. M. 1964. Coccidia (Eimeria) from the prairie dog, Cy- 
nomys ludovicianus ludovicianus, in northern Colorado. Journal of Protozoology 11: 89-91.

Wilber, P. G., D. W. Duszynski, S. J. Upton, R. S. Seville, and J. O CoRLISS. 1998. A revision of the taxonomy and nomenclature of the Eimeria spp. (Apicomplexa: Eimeriidae) from rodents in the Tribe Marmotini. Systematic Parasitology 39: 113-135.

, B. Hanelt, B. Van Horne, And D. W. Duszynski. 1994. Two new species and temporal changes in the prevalence of eimerians in a free-living population of Townsend's ground squirrels (Spermophilus townsendii) in Idaho. Journal of Parasitology 80: 251259.

Wilson, D. E., AND D. M. ReEder. 1993. Mammal species of the world, 2nd ed. Smithsonian Institution Press, Washington, D.C., $1207 \mathrm{p}$. 